Fig. 24.-Transection of appendage of eighth abdominal spiracle.

"25.-Lateral view of abdominal spiracle (I-7) covered with epithelial cells.

1. 26.-Dorsal aspect eighth abdominal spiracle.

"27.-Ventral " " "

" 28. - Third, fourth and fifth abdominal spiracles of pupa of Octotoma plicatula.

" 29--Fifth abdominal spiracle of same.

\title{
A PARASITE THE SUPPOSED CAUSE OF SOME CASES OF EPIILPSY.
}

BY G. H. FRENCH, CARBONDALE, ILLINOIS.

Gastrophilus epilepsalis, n. sp.

Larva: Length, I-I 2 inch; of the shape shown in the accompanying figure (Fig. 30), with twelve joints besides the head, or thirteen joints ; head rounded, with two brown-black hooks, the side view of the cut showing only one of them; head a little longer than broad, rounded;

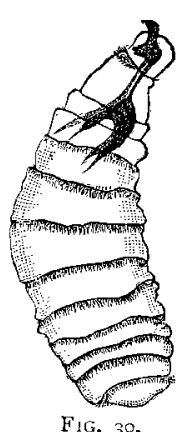
the first incisure with a patch of bristles below the hooks, but not anywhere else ; incisures 2 and 3 without bristles; incisures 4 to $\mathrm{I} 2$ armed with several rows of minute bristles, all very short except those on I 2 , pointing backward; joint 13 rounded. Extending back from the hooks and of the same colour, only in places paler, is a marking that seems to be a chitinoid support for the hooks, beneath the cuticle. Colour a dirty yellowish white.

Usually it is not wise to describe a species as new from a larva, but for the following reasons it seems best in this case. Last November, at the meeting of the Southern Illinois Medical Association, in Chester, Ill., Doctor H. C. Adderly, of that town, reported to the Association a case under his charge of a boy, then Io years old, who had been subject to epileptic spasms for four years, often having as many as twenty spasms in twenty-four hours. Upon producing a free catharthesis (the general condition of the bowels being constipated), he noticed that the excreta was "literally alive" with 
an entozoan. Some of these were sent to St. Louis for identification, but were reported as unknown to them.

With the report Dr. Adderly exhibited a few of the entozoa in a small vial of formaline. These were later brought to me by Dr. A. M. Lee, President of the Association. They were new to me. From correspondence with Dr. C. W. Stiles, of the Bureau of Animal Industry, Washington, D. C., and others, I have decided that the entozoan is new and therefore propose for it the above name. Doctors Howard and Coquillett pronounce it without hesitation the larva of a species of Gastrophilus, though in some points it seems to me to resemble some species of the allied genus Dermatobia.

For several reasons this entozoan found in the enteric canal of this boy seemed to be the cause of the epilepsy. Ist. After a free catharthesis the spasms would cease for from three to six weeks, or till a new brood were grown. 2 nd. The boy had with the spasms globus hystericus, which is reflex from the pelvic organs. 3rd. That the spasms were those of genuine epilepsy there was no doubt, as there were all the usual symptoms, including mental aberration. 4th. Two other cases of epilepsy are known to the writer where these parasites have been found, one in Chicago and the other in Sparta, Ill. 5th. Upon Dr. Adderly's changing his treatment from that usually followed in epilepsy to anthelmintics, the boy recovered, having had only one spasm since beginning that line of treatment. Under date of May rgth he writes me: "My little patient seems to be in excellent health, and I hope it will be permanent."

As to the adult state of this larva I can say nothing now, nor how it gains entrance to the human system. I had hoped to get more material before writing this, from which I might answer both of these questions, but as yet have not succeeded. But the continuous infestation of the enteric canal by dipterous larvæ is not new. Dr. J. Gasser, of the military hospital of Oran, Algeria, reports a case of ten years' standing. The date of this report was 1895 .

An interesting. exhibit prepared for the Paris Exposition is a complete set of bed hangings manufactured in Madagascar from silk procured from the halabe, an enormous spider found in certain districts of the island. Aside from being so unusual, this exhibit seems to indicate that there is a future for silk manufactured from spider's web. The matter has received the attention of $M$. Nogue, the head of the Antananarivo Technical School, who has already achieved wonderful results. Each spider yields from three to four hundred yards of silk, which can be taken from the animal every ten days, it being set free in the interval. The silk of these spiders is stated to be finer than that of the silkworm and of an extraordinary golden colour. It is extremely tenacious, and can be woven without the slightest difficulty. $-N$. Y. Post. 